Portland State University

PDXScholar

Communication Faculty Publications and

Presentations

Communication

$12-2009$

\title{
Citizens' Local Political Knowledge and the Role of Media Access
}

Lee Shaker

Portland State University, Ishaker@pdx.edu

Follow this and additional works at: https://pdxscholar.library.pdx.edu/comm_fac

Part of the Communication Technology and New Media Commons, Mass Communication Commons, and the Social Media Commons

Let us know how access to this document benefits you.

\section{Citation Details}

Published as: Shaker, L. (2009). Citizens' Local Political Knowledge and the Role of Media Access. Journalism \& Mass Communication Quarterly, 86(4), 809-826.

This Post-Print is brought to you for free and open access. It has been accepted for inclusion in Communication Faculty Publications and Presentations by an authorized administrator of PDXScholar. Please contact us if we can make this document more accessible: pdxscholar@pdx.edu. 


\section{Citizens' Local Political Knowledge and the Role of Media Access}

Scholars have long argued that local media play a critical role in shaping citizens, communities, and the interactions between them. ${ }^{1}$ Today, the local media outlets in this equation are facing significant challenges and the local media environments they are a part of are changing rapidly. ${ }^{2}$ In the midst of this shuffle, the creation and consumption of local political information (LPI) is threatened as major newspapers like the Rocky Mountain News collapse and others like the Seattle Post-Intelligencer investigate an online-only future. ${ }^{3}$ This transition raises many compelling questions about the relationship between citizens, communication, and local politics. $^{4}$

This article focuses primarily on exploring two issues: the distribution of local political knowledge throughout the population and the way that citizens' media access relates to levels of such knowledge. The first task is important because scholars do not have a clear understanding of who knows what about local politics. Bits and pieces of prior research suggest that local political knowledge differs from national political knowledge, but the nuances and generalizability of these divergences are not known. The second task is to examine the relationship between citizens' media access and their local political knowledge. Though studying media access does not directly address the decline of specific local media outlets, looking at citizens' access to various media is an indirect way of addressing the migration of media audiences. Thus, the relationship between citizens' home access to various media - newspaper delivery, cable or satellite TV, satellite radio, and the internet - and their local political knowledge sheds light upon one way that the rise of new media may affect local politics. This article also examines national political knowledge - mainly to allow direct comparisons to the exploration of local political knowledge. 


\section{Local Political Knowledge, Media, and Change}

The Importance and Distribution of Local Political Knowledge. Political knowledge depends, in part, upon access to information about governmental actions, politicians' positions, and so on. Theoretically, it is important because the more citizens know about politics, the better their political behavior will reflect their best interests, the more meaningful their engagement will be, and the better democracy works. ${ }^{5}$ Though it is not clear how much knowledge citizens require to make rational political choices, even research that contends that relatively uninformed citizens can simulate the participation of the most informed suggests that at least some knowledge is needed. ${ }^{6}$ Empirical evidence, however, shows that at the national level citizens who are White, male, older, more interested, and more socio-economically advantaged are likely to be more knowledgeable than others. ${ }^{7}$

Prior research of local political knowledge, though somewhat sparse, suggests that there are divergences in who knows about national and local affairs. ${ }^{8}$ As a fragment of a larger project, Delli Carpini and Keeter examined the relationship between demographic factors and local-level knowledge using a survey of Richmond, Virginia. ${ }^{9}$ First, they found that the level of local political knowledge did not differ statistically across gender. Second, Delli Carpini and Keeter found that Black respondents had higher levels of local knowledge than White respondents but lower levels of national knowledge. ${ }^{10}$ Similarly, in a study using data from Seattle, Moy and colleagues found that levels of local political knowledge did not differ across gender but that non-White respondents were more knowledgeable. ${ }^{11}$

The Relationship Between Media and Local Political Knowledge. It seems an almost prima facie truth that citizens' media diets must be related to their political knowledge. Yet, the connection between media, political learning, and political knowledge is not clear. ${ }^{12}$ A growing 
body of literature addresses this relationship. First, Eveland and his colleagues have scrutinized panel data and argue that citizens' news consumption has a causal impact upon their political knowledge. ${ }^{13}$ Barabas \& Jerit offer compelling evidence that the volume, prominence, and breadth of mass-mediated political information are positively connected to citizens' knowledge. ${ }^{14}$ And, while citizens may certainly learn about local politics through direct experience and interpersonal communication, media are an important source of mobilizing information and conversational grist. ${ }^{15}$ Taken together, this research suggests that a causal relationship between media use and knowledge exists and that media which contain political information should be seen as a vital part of democracy.

Turning to local affairs, there is some support from survey-based research for the notion that local news media use is an important factor in predicting citizens' local political knowledge. The most direct evidence comes from a study of the 1979 Columbus, Ohio election that found positive correlations between three media usage variables - newspaper readership, viewership of local TV news, listnership to radio news - and knowledge of the mayoral and council candidates. ${ }^{16}$ Scheufele and colleagues found that newspaper use was significantly related to respondents' awareness of the existence of a local issue. ${ }^{17}$ Similarly, with a Seattle-area survey, another study found that using local media enhanced citizens' perceptions of knowledge. ${ }^{18}$ This vein of research indicates that a relationship between the consumption of mass-mediated LPI and local political knowledge is likely - but the prior research clearly leaves room for further exploration.

A related strand of research suggests that simply being able to access LPI is important to citizens' knowledge. Generally, higher levels of information about an issue in the media environment elevate citizen knowledge of the issue - regardless of citizens' levels of interest or 
capacity. ${ }^{19}$ For example, Delli Carpini and colleagues found a clear correlation between the availability of information about state politics in a city's media environment and the level of knowledge the city's residents had of state politics. ${ }^{20}$ Similarly, Zukin and Snyder took advantage of a naturally occurring dichotomy in New Jersey's media environment to show differences in passive learning. ${ }^{21}$ In areas served by New York-based media, citizens learned about New York's mayoral campaign more than citizens in areas served by Philadelphia-based media - even though neither population had instrumental use for this information. Motivation and capacity are also critical factors in shaping what citizens glean from media (and knowledge gaps among citizens can be expected), but this body of research makes the case that the structure of citizens' information environments is an important issue in and of itself. ${ }^{22}$

A Changing Media Environment. At the start of the $21^{\text {st }}$ century, it is clear that the rise of electronic and 'new' media are dramatically reshaping the ways that citizens seek and receive all sorts of information. ${ }^{23}$ Circulation and survey data show that, at best, only about half of Americans read a newspaper (online or offline) regularly. ${ }^{24}$ Viewership of local news is declining as well. In 1993, 77\% of survey respondents reported regularly watching local news; by 2008 , this figure was down to $52 \% .{ }^{25}$ Meanwhile, the number of internet users continues to increase, reaching $73 \%$ of all American adults - approximately 55\% of whom have broadband at home today. ${ }^{26}$

The near-infinite array of media choices now available to consumers forces local media into constant and direct competition with better funded, more polished options. ${ }^{27}$ Gone are the days when a viewer's choice at 6 or 11 was local news, local news, or a rerun of an old sitcom. Instead, the audience can easily click from their local broadcast network to the niche-targeted network most interesting to them or use the web to find other appealing content. Such 
competition for an audience threatens the profitability of local news. Combined with the expectations of Wall Street, this profit pressure leads media conglomerates to run radio, television, and print outlets from a national platform that results in downsizing local news staffs - which erodes their ability to contribute meaningfully to a community. ${ }^{28}$ And, recent events in the newspaper industry show that the migration of audiences threatens even the existence of local media outlets. ${ }^{29}$ So, both the quantity and quality local news is threatened as the universe of media choices available to citizens increases.

As this transition in the media environment continues, it is possible that new, alternative sources of LPI might supplant traditional local news outlets. Some scholars and pundits voice optimism about the potential of new media. ${ }^{30}$ There are some examples - like everyblock.com of the use of technology to facilitate access to LPI. But, there is little evidence of the viability or adoption of these efforts. And, aside from macro-level circulation and ratings data, there has been little research into how citizens are getting LPI today. Though there is a trickle of research that examines the effects of new media on national political concerns, there is scant research of the possible effects of the changing media environment on local politics.

\section{Hypotheses \& Theory}

This study draws upon two bodies of theory to elucidate our understanding of citizens' levels of local political knowledge. The basic theoretical approach invokes conceptualizations of information selectivity and salience to explain the relationship between demographics factors and local political knowledge. In addition, the theoretical consequences of choice are included to aid the examination of the relationship between citizens' media access and their local political knowledge. 
Race, Gender and Knowledge. The initial priority of this article is to replicate previously observed patterns of local political knowledge in the population - this time in Philadelphia, a city with nearly equal Black and White communities (each group is about $45 \%$ of the city's total population). As previously discussed, these patterns differ markedly from those seen at the national level and the dataset used here (and described below) allows for a direct comparison to illustrate these divergences.

One long-running thread of political science research holds that individuals are incapable of being universally informed about politics and instead focus on issues of personal or group relevance. ${ }^{31}$ Hutchings argues that - given properly conceptualized links between social groups and issue salience - knowledge specialization does exist among the citizenry. ${ }^{32}$ A pertinent example of this is found in an article by Bobo and Gilliam that reports that Black citizens' group salience and, consequently their attentiveness, is triggered when a Black mayor is in office. ${ }^{33}$ While controlling for demographic differences, they find that Black citizens know more about local politics when their community has a Black mayor (because this signals a political environment that will better serve their interests). This finding echoes Delli Carpini and Keeter's previously-mentioned work in Richmond, Virginia, where Black citizens were more knowledgeable overall about local politics than their White peers. ${ }^{34}$ Here, the mayor was not Black, but the city manager and superintendent of schools were and Black respondents were more likely to successfully name these officials than White respondents. In the election this article deals with, three of the five Democratic primary candidates were Black, the Democratic nominee (and eventual victor, Michael Nutter) was Black, and the term-limited incumbent mayor - John Street - was Black. 
Another example of a salience variation is the notion that mothers are particularly interested in the education of their children - primarily a local concern - and thus have a signature issue that drives local political knowledge and engagement. ${ }^{35}$ This, in turn, prompts a different distribution of knowledge across gender at the local level than at the national level. Such issue salience differences, paired with the notion that local politics are more immediate and comprehensible than national affairs, ground the differences in the distribution of local and national political knowledge among the public predicted by Hypotheses 1-2C.

H1: National political knowledge will be higher among respondents who are White, wealthy, educated, older, and male.

H2A: Local political knowledge will not differ significantly across gender. H2B: Local political knowledge will be greater among non-White respondents. H2C: Local political knowledge will be greater among older, wealthier, and more educated respondents.

Media Access and Knowledge. The second set of hypotheses in this article predicts the effects of home access to different media upon citizens' local and national political knowledge. As described above, prior research indicates that being situated in a media environment that contains specific political information is correlated with citizens' level of knowledge about these topics even when controlling for other explanatory variables. The recent proliferation of media allows citizens' media environments to be increasingly individualized. With this in mind, the choices citizens make to construct their own information ecologies become more relevant to the media environment-and-knowledge equation.

A small but useful body of work explores the implications of increasing media choice. In an experimental study, Atre and Katz find that the mere increase of available television channels decreases the selection of news programming. ${ }^{36}$ Further, they found that as choice increases, subjects were more likely to choose content from their preferred genre - a result that is 
consonant with Webster's prediction that increased choice would yield a narrowed media diet. ${ }^{37}$ Prior has argued that the impact of access to more media choice on national political knowledge is moderated by individuals' preference for news versus entertainment programming. ${ }^{38} \mathrm{He}$ finds that the distribution of national political knowledge in the population today suggests that a greater gap is forming between those who are very knowledgeable and those who are not very knowledgeable, with fewer citizens occupying the middle ground.

As media choice increases, access to all kinds of information increases. Even if the mix of available information varies, greater media choice affords citizens greater access to national political information. The onus is on citizens to select the sorts of media and information to consume - which is what makes Prior's news or entertainment preference variable insightful. For LPI, the relationship between choice expansion and increased access to information is more tenuous. In the abstract, increased media access - particularly with the rise of the internet - does expand the availability of LPI. But, as described above, the new media environment also poses major challenges to the production and consumption of LPI. With this in mind, an information preference variable may not be necessary in locating the effects of increased media access upon local political knowledge. Instead, greater media access may simply lead to lower levels of local political knowledge.

H4A-D specify the predicted effect of citizens' media access upon their local political knowledge. Macro-level media data indicate that a transition from locally-based media to national media is underway. Citizens whose media environments expand to include more national news and entertainment - but not more local news - are likely to change their media diets accordingly. Newspapers have long been the backbone of American local political communities and $\mathrm{H} 4 \mathrm{~A}$ accordingly predicts a positive relationship between newspaper home 
delivery and local political knowledge. ${ }^{39}$ In contrast with national political information, cable television does not offer a similar expansion of the available LPI. Though many cable systems provide some kind of bulletin board or television channel, the development of these resources has been anemic. Likewise, satellite radio contains no specifically local information other than brief traffic and weather updates. Consequently, H4B and $\mathrm{H} 4 \mathrm{C}$ predict a negative relationship between access to multichannel TV or satellite radio and local political knowledge because the available LPI faces increased competition for citizens' attention. Similarly, H4D predicts a negative relationship between home internet access and local political knowledge. The rationale for this hypothesis is that though the internet increases access to a world of information, LPI is a very small amount of what is available. Further, LPI shifts from center stage in the local newspapers or local TV news to a place in the chorus where it is much less prominent.

H3: National political knowledge will not differ significantly among citizens with and without home delivery of a local newspaper, home access to cable (or satellite) TV, home or car access to satellite radio, or home access to the internet.

H4A: Local political knowledge will be higher among citizens who have home delivery of a newspaper.

H4B: Local political knowledge will be lower among citizens who have cable (or satellite) television at home.

H4C: Local political knowledge will be lower among citizens who have satellite radio at home or in their cars.

H4D: Local political knowledge will be lower among citizens who have internet access at home.

\section{Data \& Methods}

The analyses in this article use a dataset from a random digit dialing (RDD) survey of 1001 Philadelphians administered by SRBI of New York City. The survey was conducted from November $7^{\text {th }}-21^{\text {st }}$ after the Philadelphia mayoral election in order to reach citizens during a high-salience time for local politics. The election was for an open seat and no major state or national elections took place that day. SRBI's interviewers were trained in advance, a live test of 
the instrument was performed, and calls were monitored at the outset to ensure that the survey was being properly conducted. The response rate, defined by the American Association for Public Opinion Research (AAPOR) as RR4, was 21.6\%. This figure reflects refusals as well as non-contacts; given the increasing difficulty in completing telephone surveys the response rate was satisfactory if not ideal.

Though citizens' local political knowledge is the primary focus of this piece, national political knowledge items were included in the survey and are analyzed as well. Identical regression models that predict local or national political knowledge are constructed for two reasons. First, since national political knowledge has been studied thoroughly, the extent to which the results of similar analysis from this dataset are in accordance with prior research confirms the reliability of the data used here. Second, and more importantly, differences between the national and local political knowledge models support the notion that local political knowledge is a unique substance that requires dedicated research.

This study tested the hypotheses using hierarchical multiple regressions in which the independent variables were entered into the model in two blocks that contain identical independent variables across both models. The first block contains demographic and political interest variables. The second block contains the media access variables, allowing for the determination of the cumulative contribution of the media access variables upon the prediction of the dependent variables after the other independent variables have been considered.

Univariate Summary. An overview of the survey sample suggests that it roughly approximated the population of Philadelphia. ${ }^{40}$ In the regressions below, age $(\mathrm{M}=50.1, \mathrm{SD}=$ 17.1) is included as a continuous variable. Gender is included as a dichotomous $0-1$ variable with male $(48 \%)$ equal to 1 . Income was coded into four categories $(M=2.1, S D=1.0)$ : less than 
$\$ 30,000(30 \%), \$ 30,000$ to $\$ 60,000(40 \%), \$ 60,000$ to $\$ 100,000(13 \%)$, and more than $\$ 100,000$ $(13 \%) .{ }^{41}$ Race is included as pair of dichotomous variables for Black (45\%) and other (9\%) respondents with White (45\%) respondents as the reference group. Finally, education is included as a five-point variable $(\mathrm{M}=2.9, \mathrm{SD}=1.2)$ : less than high school $(9 \%)$, high school graduate (35\%), some post-secondary education $(26 \%)$, college graduate $(18 \%)$, and some graduate school and beyond (13\%).

National and local political interest variables are both included in the models below. Political interest has been shown to be a critical factor in predicting citizens' political knowledge and its inclusion nods towards the importance of citizens' motivation. ${ }^{42}$ The national and local political interest variables are derived from a pair of four-point Likert-type items that range from "1 - not at all interested" to "4 - very interested." National political interest $(\mathrm{M}=2.9, \mathrm{SD}=1.0)$ and local political interest $(\mathrm{M}=3.1, \mathrm{SD}=.9)$ are positively correlated $(\mathrm{R}=.59, \mathrm{p} \leq .001)$ but are included separately in both models below as a test of their discriminant validity and to allow for direct comparison between the national and local political knowledge models.

Finally, four home media access variables are included: cable (or satellite) TV access, internet access, delivery of a local newspaper, and home or car access to satellite radio. In the sample, $77 \%$ of respondents report having cable (or satellite) TV, $65 \%$ have internet access, $38 \%$ have a local newspaper delivered, and $12 \%$ have satellite radio access. Each of these variables is included as a dichotomous 0-1 variable that equals 1 when respondents report having access. Collinearity statistics (tolerance and VIF) indicated that the simultaneous inclusion of all these variables (media access and demographic) was not problematic.

The two dependent variables are indices of local and national political knowledge that were adapted from prior research (see items in Appendix A). Multiple-choice options were not 
provided. The mean of each respondents' answers ( 0 for an incorrect answer, 1 for a correct answer) was calculated in order to create the two indices. Both range from 0 (low) to 1 (high). On average, respondents scored slightly lower on the national political knowledge index (Chronbach's $\alpha=.74, \mathrm{M}=.50, \mathrm{SD}=.30$ ) than on the local political knowledge index (Chronbach's $\alpha=.77, \mathrm{M}=.52, \mathrm{SD}=.29$ ).

[Table 1 about here]

\section{Results}

Bivariate Relationships. There are clear differences in the correlates of local and national political knowledge (Table 1). The correlations between the independent variables and national political knowledge largely conform to expectations. All of the basic demographic variables race (White: $\mathrm{R}=.31$; Black: $\mathrm{R}=-.20$; other: $\mathrm{R}=-.10)$, gender (male: $\mathrm{R}=.17$ ), age $(\mathrm{R}=.18$ ), income $(\mathrm{R}=.38)$, and education $(\mathrm{R}=.43)$ - are significantly correlated with national knowledge $(\mathrm{p} \leq .01)$ and in the direction anticipated. At the local level, two of these correlations are not present: there is no significant correlation along gender lines and the correlation according to race is a mixed bag (White: $\mathrm{R}=.18, \mathrm{p} \leq .01$; Black: $\mathrm{R}=-.03, \mathrm{~N} / \mathrm{S}$; other: $\mathrm{R}=-.12, \mathrm{p} \leq .01$ ). These relationships indicate that the predictors of political knowledge at the local and national levels may diverge in the regression models.

Among the media access variables, home newspaper delivery is positively correlated with both local $(\mathrm{R}=.24, \mathrm{p} \leq .01)$ and national $(\mathrm{R}=.17, \mathrm{p} \leq .01)$ political knowledge. Home internet access is also positively correlated with both local $(\mathrm{R}=.17, \mathrm{p} \leq .01)$ and national $(\mathrm{R}=.22, \mathrm{p} \leq$ .01) political knowledge - though the relative strength of the relationships is inverted in comparison to those seen with home newspaper delivery. Neither cable TV nor satellite radio access has a significant correlation with either local or national political knowledge. Taken at 
face value, these correlations do not suggest any large departures in the way that media access relates to local versus national political knowledge.

National Political Knowledge. Table 2 provides the results of a hierarchical OLS regression predicting national political knowledge. Overall, the model presented here fits well: the final $\mathrm{R}^{2}$ is $42.4 \%$. The great bulk of the variance explained is captured by the demographic and interest block which has a partial $\mathrm{R}^{2}$ of $41.7 \% .^{43}$ The media access variables cumulatively make a small, but significant, contribution to the final $\mathrm{R}^{2}$ of $.6 \%(\mathrm{p} \leq .05)$.

\section{[Table 2 about here]}

The findings here are largely consonant with prior research that depicts the relationship between demographic factors and national political knowledge. ${ }^{44} \mathbf{H 1}$ is supported: national political knowledge is higher among respondents who are White, wealthy, educated, older, and male. Support for $\mathbf{H 3}$ - the only other hypothesis that relates to national political knowledge - is strong but not quite as unequivocal. There is no significant difference in the level of national political knowledge among citizens who have home delivery of a local newspaper, cable (or satellite) TV access, or satellite radio access and those who do not. However, citizens with home internet access are significantly more knowledgeable about national politics $(\beta=.06, \mathrm{p} \leq .05)$ than those without such access.

\section{[Table 3 about here]}

Local Political Knowledge. The local political knowledge model in Table 3 also fits well, with an overall $\mathrm{R}^{2}$ of $29.1 \%$. The demographic and interest variables capture $27.3 \%$ of this variance; the media access variables' partial $\mathrm{R}^{2}$ is $1.8 \%(\mathrm{p} \leq .001)$. The first set of hypotheses relating to local political knowledge consider a series of demographic variables. H2A - which predicts that local political knowledge will not differ significantly across gender - is supported. 
H2B predicts that local political knowledge will be greater among non-White respondents; this hypothesis is not supported. Instead, there are no so significant differences in local political knowledge across race (Black: $\beta=.01$, n.s.; Other: $\beta=-.06$, n.s.). Though this hypothesis is not fully supported, the divergence from the racial gap in knowledge seen at the national level should still be noted. H2C is supported as older, wealthier, and more educated respondents are significantly more knowledgeable about local politics.

H4A-D predict the relationships between citizens' media access and their local political knowledge. H4A - which predicts that citizens who have a newspaper delivered to their home will be more knowledgeable about local politics than those who do not - is supported by the model in Table 3. A significant, negative relationship exists between cable TV access and local political knowledge $(\beta=-.06, p \leq .05)$, supporting H4B. This result should be viewed in the context of three other points: first, there is no correlation between cable access and local political knowledge; second, the regression predicting national political knowledge did not find a similar result; third, there are significant, positive relationships between SES variables and both local political knowledge and cable access. Given these factors, the negative relationship between cable TV access and local political knowledge is a reversal - though it is not entirely unexpected.

Turning to $\mathbf{H 4 C}$, there is no significant difference in the level of local political knowledge among citizens with or without satellite radio access $(\beta=-.05$, n.s. $)$. And, there is a significant, positive relationship between home internet access and the dependent variable $(\beta=$ $.07, \mathrm{p} \leq .05)$. This relationship is the opposite of what H4D predicted. Though the effect size of the media access variables is modest, the partial $\mathrm{R}^{2}$ of their block and their relative large size in comparison to the values seen in the national political knowledge model suggests that media access is a somewhat more important factor in citizens' local political knowledge. 


\section{Discussion \& Conclusion}

Prior researchers have depicted the contours of national political knowledge and, to a much lesser extent, local political knowledge. Though not all of the hypotheses were supported in this article, the results reported here reaffirm that local and national political knowledge are distributed throughout the population in different patterns. This discussion focuses solely upon local political knowledge and considers the implications of the results reported above and some possible explanations for them.

First, in the model predicting local political knowledge, women and minority respondents closed the knowledge gaps that are observed at the national level: there were no significant differences in local political knowledge across race or gender. Because the pattern of local political knowledge in a community's population is non-generalizable and may be attributed to the unique features of that community, the repeated corroboration of similar local-level findings is notable. Philadelphia, the setting of this research, is starkly different in many ways (political culture, citizen make-up, media market) from Richmond, ${ }^{45}$ Seattle, ${ }^{46}$ or Madison. ${ }^{47}$ The extent to which the predictors of local political knowledge are consistent across these settings - and consistently different from those of national political knowledge - bolsters the conclusion that local political knowledge is a qualitatively different substance than national political knowledge. As such, it may be more akin to policy-specific knowledge that is driven by issue salience. ${ }^{48}$ Perhaps most interesting are the findings that indicate that media access bears significantly upon citizens' local political knowledge. This affirms one of this paper's key underlying premises: changes in the media environment have tangible implications for local politics. The particulars of the effect of increased media access upon local political knowledge require additional explanation. First, home access to cable (or satellite) TV is negatively related 
with local - but not national - political knowledge. This conforms to the hypothesized predictions and is a reversal of what might be expected from the non-significant correlation (Table 1) between cable access and both local and national political knowledge. Because cable access is positively correlated with income $(\mathrm{R}=.20, \mathrm{p} \leq .01)$ and education $(\mathrm{R}=.07, \mathrm{p} \leq .05)$, the reversal in the regression model seems to be due to disentangling these interrelated variables. Though time spent with television has not decreased in recent years, viewership of local news has plummeted and cable is one plausible culprit. ${ }^{49}$ This trend does not bode well for the public's awareness of local affairs, and this finding suggests that there is a real problem.

This problem is exacerbated by the rapid decline of local newspapers. The results in Table 3 depicted a very strong relationship between home delivery of a local newspaper and local political knowledge. As these newspapers falter and perhaps even fail, it is realistic to wonder where citizens will get LPI. Without such information, they will certainly struggle to be knowledgeable about their communities. And, though home internet access was positively related to local political knowledge in this study, the relevant content online is often driven by what is produced by local newspapers and TV newscasts. In other words, the problem wrought by increasing media access is not limited to only the citizens who opt for non-local content: their choices lead to a spiral that may result in the elimination of local choices for all citizens. The positive relationship between internet access and local political knowledge may be grounds for cautious optimism - or it could be a spurious result that reflects the socioeconomic advantages of the people who have such access. ${ }^{50}$ If the latter is true, the transition by citizens to new media outlets may have uniformly negative consequences for levels of local political knowledge. The negative bearing of cable TV access in this paper is the canary in the coal mine for such a 
scenario: it portends a society in which citizens are less knowledgeable about local affairs even if (and when) a viable model for producing local political information is successfully developed.

The research presented here meaningfully extends scholarly knowledge of local political knowledge. Foremost among the findings is the relevance of citizens' media environments to their local political knowledge. This result - paired with the largely null finding at the nationallevel - supports the premise that the proliferation of new media has unique and possibly negative consequences for local politics. There is a possibility that the expansion of LPI offerings online may be beneficial, but this outcome is far from assured. 


\section{Appendix A: Survey Items for Knowledge Indices}

\section{$\underline{\text { National Political Knowledge (\% correct response) }}$}

1. Do you happen to know what job or political office is now held by Dick Cheney? (68\%)

2. Whose responsibility is it to determine if a law is constitutional or not? (34\%)

3. How much of a majority is required for the U.S. Senate and House of Representatives to override a presidential veto? $(27 \%)$

4. Do you happen to know which party currently has the most members in the House of Representatives in Washington? (60\%)

5. Do you happen to know whether President Bush vetoed, or signed, a recent bill designed to increase spending for children's health insurance? (61\%)

\section{Local Political Knowledge (\% correct response)}

1. Do you happen to know what position Paul Vallas resigned from recently in Philadelphia? ${ }^{\mathrm{a}}$ $(41 \%)$

2. Do you know what position John Timoney held in Philadelphia? ${ }^{\mathrm{b}}$ (71\%)

3. Do you happen to know why John Street did not run again for mayor in this election? ${ }^{\mathrm{c}}$ (58\%)

4. Can you tell me which Democratic candidate for mayor advocated for a 'stop-and-frisk' gun policy during the primary campaign? ${ }^{\mathrm{d}}(62 \%)$

5. Can you tell me which Democratic candidate for mayor used his own money to fund his primary campaign? ${ }^{\mathrm{e}}(14 \%)$

6. Can you tell me who the Republican candidate for mayor was this year? ${ }^{\mathrm{f}}(35 \%)$

7. Can you tell me who won the general election for mayor? ${ }^{\mathrm{d}}(82 \%)$

${ }^{\text {a }}$ Paul Vallas was the CEO of School District of Philadelphia for 5 years before resigning in 2007. Vallas is White.

${ }^{\mathrm{b}}$ John Timoney was the Chief of Police in Philadelphia from 1998-2001. Timoney is White.

${ }^{\mathrm{c}}$ John Street was the mayor of Philadelphia from 2000-2008. He is Black and did not run because of term limits.

${ }^{d}$ Michael Nutter, the victor of the 2007 Philadelphia mayoral election, strongly supported a 'stop-and-frisk' policy. Nutter is Black.

${ }^{\mathrm{e}}$ Tom Knox, who is White, spent $\$ 8$ million out of pocket on his bid for the Democratic bid and finished $2^{\text {nd }}$.

${ }^{\mathrm{f}} \mathrm{Al}$ Taubenberger, who is White, mounted a half-hearted campaign as the Republican candidate for mayor, finishing with $17 \%$ of the vote. 


\section{Table 1: Bivariate Correlations}

\begin{tabular}{lcc}
\hline Independent Variables & $\begin{array}{c}\text { Local Political } \\
\text { Knowledge }\end{array}$ & $\begin{array}{c}\text { National Political } \\
\text { Knowledge }\end{array}$ \\
\hline White & $.18^{* *}$ & $.31^{* *}$ \\
Black & -.03 & $-.20^{* *}$ \\
Other & $-.12^{* *}$ & $-.10^{* *}$ \\
Male & .06 & $.17^{* *}$ \\
Age & $.16^{* *}$ & $.18^{* *}$ \\
Income & $.31^{* *}$ & $.38^{* *}$ \\
Education & $.30^{* *}$ & $.43^{* *}$ \\
National Interest & $.35^{* *}$ & $.47^{* *}$ \\
Local Interest & $.38^{* *}$ & $.32^{* *}$ \\
Newspaper Delivery & $.24^{* *}$ & $.17^{* *}$ \\
Cable/Satellite TV Access & .06 & .05 \\
Satellite Radio Access & .01 & -.01 \\
Internet Access & $.17^{* *}$ & $.22^{* *}$ \\
$* \mathrm{p} \leq .05 * * \mathrm{p} \leq .01$ & &
\end{tabular}

Table 2: OLS Regression Predicting National Political Knowledge

\begin{tabular}{lcc}
\hline Independent Variables & National Political Knowledge & \\
\hline & $\underline{B(S E)}$ & $\underline{3}$ \\
Demographics \& Interest & $-.101(.018)^{* * *}$ & -.15 \\
$\quad$ Black & $-.102(.032)^{* * *}$ & -.09 \\
Other & $.083(.017)^{* * *}$ & .13 \\
Male & $.004(.001)^{* * * *}$ & .18 \\
Age & $.026(.005)^{* * *}$ & .18 \\
Income & $.072(.008)^{* * *}$ & .26 \\
Education & $.077(.011)^{* * *}$ & .23 \\
National Political Interest & $.022(.011)$ & .06 \\
Local Political Interest & & $41.7 * * *$ \\
$\quad \mathrm{R}^{2}(\%)$ & $.007(.018)$ & .02 \\
Media Variables & $-.037(.021)$ & -.05 \\
$\quad$ Newspaper Delivery & $-.047(.027)$ & -.05 \\
Cable/Satellite TV Access & $.042(.021)^{* *}$ & .06 \\
Satellite Radio Access & & $.6 *$ \\
Internet Access & & 42.4 \\
Incremental $\mathrm{R}^{2}(\%)$ & & 923 \\
$\mathrm{R}^{2}(\%)$ & & \\
$\mathrm{N}$ & & \\
$* \mathrm{p} \leq .05 * * \mathrm{p} \leq .01 * * * \mathrm{p} \leq .001$ & & \\
\end{tabular}


Table 3: OLS Regression Predicting Local Political Knowledge

\begin{tabular}{|c|c|c|}
\hline Independent Variables & Local Political Knowledge & \\
\hline & $\underline{B(S E)}$ & $\underline{\beta}$ \\
\hline \multicolumn{3}{|l|}{ Demographics \& Interest } \\
\hline Black & $.004(.017)$ & .01 \\
\hline Other & $-.057(.031)$ & -.06 \\
\hline Male & $.019(.016)$ & .03 \\
\hline Age & $.002(.001)^{* * *}$ & .15 \\
\hline Income & $.026(.004)^{* * *}$ & .21 \\
\hline Education & $.036(.008)^{* * *}$ & .15 \\
\hline National Political Interest & $.014(.011)$ & .05 \\
\hline Local Political Interest & $.074(.011)^{* * *}$ & .24 \\
\hline $\mathrm{R}^{2}(\%)$ & & $27.3^{* * *}$ \\
\hline \multicolumn{3}{|l|}{ Media Variables } \\
\hline Newspaper Delivery & $.066(.018)^{* * *}$ & .11 \\
\hline Cable/Satellite TV Access & $-.040(.020)^{*}$ & -.06 \\
\hline Satellite Radio Access & $-.044(.026)$ & -.05 \\
\hline Internet Access & $.039(.020)^{*}$ & .07 \\
\hline Incremental $\mathrm{R}^{2}(\%)$ & & $1.8^{* * *}$ \\
\hline $\mathrm{R}^{2}$ & & 29.1 \\
\hline $\mathrm{N}$ & & 923 \\
\hline
\end{tabular}

${ }^{1}$ See, for example, Alexis de Toqueville, Democracy in America. Volume 2. From the Henry Reeve Translation, revised and corrected. http://xroads.virginia.edu/ HYPER/DETOC/toc indx.html (accessed March 11, 2009); Phyllis Kaniss, Making Local News (Chicago: University of Chicago Press, 1991); Robert E. Park, Society (New York: Free Press, 1955).

${ }^{2}$ Project for Excellence in Journalism, "The State of the News Media 2008," http://www.stateofthenewsmedia.com/2008/ (accessed March 2, 2009).

${ }^{3}$ William Yardley and Richard Perez-Pena, "Seattle Paper Shifts Entirely to the Web," New York Times March 17, 2009, http://www.nytimes.com/2009/03/17/business/media/17paper.html.

${ }^{4}$ The 'local political information' that this article refers to is information about a community's characteristics, its salient issues, and the practice of local politics. As such, it differs from national, or general, political information not in provenance but in topic. In other words, it is information about local politics, not information provided by local sources about politics in general.

${ }^{5}$ Michael X. Delli Carpini and Scott Keeter, What Americans Know About Politics and Why it Matters (New Haven, CT: Yale University Press, 1996).

${ }^{6}$ Robert E. Lane and David O. Sears, Public Opinion (Englewood Cliffs, NJ: Prentice Hall, 1964).

${ }^{7}$ Delli Carpini and Keeter, "What Americans Know About Politics and Why it Matters"; Dan Drew and David Weaver, "Voter Learning in the 2004 Presidential Election: Did the Media Matter?" Journalism and Mass Communication Quarterly 83 (Spring 2006): 25-42.

${ }^{8}$ Delli Carpini and Keeter, "What Americans Know About Politics and Why it Matters"; John McLeod, Dietram Scheufele and Patricia Moy, "Community, Communication, and Participation: The Role of Mass Media and Interpersonal Discussion in Local Political Participation," Political Communication 16 (Autumn 1999): 315-336; Patricia Moy et al., "Political Correlates of Local News Media Use," Journal of Communication 54 (Autumn 2004): 532-546; Dietram Scheufele, James Shanahan, and Sei-Hill Kim, "Who Cares About Local Politics? Media Influences on Local Political Involvement, Issue Awareness, and Attitudes Strength," Journalism and Mass Communication Quarterly 79 (Summer 2002): 427-444.

${ }^{9}$ Delli Carpini and Keeter, "What Americans Know About Politics and Why it Matters." 
${ }^{10}$ Delli Carpini and Keeter included some basic media variables as well, finding that general newspaper use - but not radio or TV use - was significantly correlated with local political knowledge.

${ }^{11}$ Moy et al., "Political Correlates of Local News Media Use."

12 Jason Barabas and Jennifer Jerit, "Estimating the Causal Effects of Media Coverage on Policy-Specific

Knowledge," American Journal of Political Science 53 (Winter 2009): 73-89.

${ }^{13}$ William Eveland et al., "Understanding the Relationship Between Communication and Political Knowledge: A Model Comparison Approach Using Panel Data," Political Communication 22 (Autumn 2005): 423-446.

${ }^{14}$ Barabas and Jerit, "Estimating the Causal Effects of Media Coverage on Policy-Specific Knowledge."

${ }^{15}$ Elihu Katz and Paul Lazarsfeld, Personal Influence (New York: Columbia University Press, 1955); McLeod, Scheufele, and Moy, "Community, Communication, and Participation: The Role of Mass Media and Interpersonal Discussion in Local Political Participation."

${ }^{16}$ Lee B. Becker and Sharon Dunwoody, "Media Use, Public Affairs Knowledge, And Voting in a Local Election," Journalism Quarterly 59 (Summer 1982): 212-218.

${ }^{17}$ Dietram Scheufele et al., "Social Structure and Citizenship," Political Communication 21 (Autumn 2004): 315338.

${ }^{18}$ Moy et al., "Political Correlates of Local News Media Use."

${ }^{19}$ Barabas and Jerit, "Estimating the Causal Effects of Media Coverage on Policy-Specific Knowledge."

${ }^{20}$ Michael X. Delli Carpini, Scott Keeter, and J. David Kennamer, "Effects of the News Media

Environment on Citizen Knowledge of State Politics and Government," Journalism and Mass Communication Quarterly 71 (Summer 1994): 443-456.

${ }^{21}$ Cliff Zukin and Robin Snyder, "Passive Learning: When the Media Environment Is the Message," Public Opinion Quarterly 48 (1984): 629-638.

${ }^{22}$ Philip Tichenor, George Donohue, and Clarice Olien, "Mass Media Flow and Differential Growth in Knowledge,” Public Opinion Quarterly 34 (1970): 159; Michael McDevitt and Steven Chaffee, “Closing Gaps in Political Communication and Knowledge: Effects of a Social Intervention," Communication Research 27 (Summer 2000): 259-292.

${ }^{23}$ PEJ, "The State of the News Media 2008."

${ }^{24}$ Douglas Ahlers, "News Consumption and the New Electronic Media," Harvard International Journal of Press and Politics 11 (Winter 1991): 29-52; Pew Research Center for the People and the Press, "Online Papers Modestly Boost Newspaper Readership,” http://people-press.org/report/282/online-papers-modestly-boost-newspaper-readership (accessed March 11, 2009).

${ }^{25}$ Pew Research Center for the People and the Press, "Key News Audiences Now Blend Online and Traditional Sources," http://people-press.org/reports/pdf/444.pdf (accessed March 11, 2009).

${ }^{26}$ Pew Internet and American Life Project, "Home Broadband 2008," http://www.pewinternet.org/pdfs/PIP_Broadband_2008.pdf (accessed March 11, 2009).

${ }^{27}$ Markus Prior, Post-broadcast Democracy: How Media Choice Increases Inequality in Political Involvement and Polarizes Elections (New York: Cambridge University Press, 2007).

${ }^{28}$ Eric Klinenberg, Fighting for Air: The Battle to Control America's Media (New York: Metropolitan Books, 2007); Robert W. McChesney, Our Media, Not Theirs: The Democratic Struggle Against Corporate Media (New York: Seven Stories Press, 2002).

${ }^{29}$ Yardley and Perez-Pena, "Seattle Paper Shifts Entirely to the Web."

${ }^{30}$ Yochai Benkler, The Wealth of Networks: How Social Production Transforms Markets and Freedom (New Haven, CT: Yale University Press, 2006).

${ }^{31}$ Bernard Berelson, Paul Lazarsfeld, and William McPhee, Voting (Chicago: University of Chicago Press, 1954); Philip Converse, "The Nature of Belief Systems in Mass Publics," in Ideology and Discontent, D.E. Apter, (New York: Free Press, 1964).

${ }^{32}$ Vincent Hutchings, "Political Context, Issue Salience, and Selective Attentiveness: Constituent Knowledge of the Clarence Thomas Confirmation Vote," Journal of Politics 63 (Autumn 2001): 846-868.

${ }^{33}$ Lawrence Bobo and Franklin Gilliam, "Race, Sociopolitical Participation, and Black Empowerment," American Political Science Review 84 (Spring 1990): 377-393.

${ }^{34}$ Delli Carpini and Keeter, "What Americans Know About Politics and Why it Matters."

35 Burns, Schlozman, and Verba, "The Private Roots of Public Action: Gender, Equality, and Political Participation."

${ }^{36}$ Jatin Atre and Elihu Katz, "What's killing television news? Experimentally assessing the effects of multiple channels on media choice" (annual meeting, International Communication Association, New York City, 2005). 
${ }^{37}$ James Webster, "Audience behavior in the new media environment," Journal of Communication 36 (Winter 1986): 77-91.

${ }^{38}$ Prior, "Post-broadcast Democracy: How Media Choice Increases Inequality in Political Involvement and Polarizes Elections."

${ }^{39}$ Kaniss, "Making Local News."

${ }^{40}$ The sample drawn for this study fairly reflects the city of Philadelphia's population, though levels of education and income appear to be slightly high. For an overview of the city's demographics, visit http://quickfacts.census.gov/qfd/states/42/42101.html.

${ }^{41}$ In line with other survey research, $17 \%$ of respondents either did not know their annual household income or refused to answer the question. After using single-item imputation, an income response was available for $96 \%$ of respondents. An income for respondents that did not volunteer one was tabulated by substituting the mean income level of other respondents in the same zip code who did provide an income. $4 \%$ of survey respondents provided neither an income nor a zip code and, consequently, are dropped from the multivariate analyses.

${ }^{42}$ Delli Carpini and Keeter, "What Americans Know About Politics and Why it Matters."

${ }^{43}$ National and local political interest are included in both regression models presented in this paper for two reasons. First, including both makes the two models identical aside from the dependent variables. This allows for clearer comparison. Second, including both interest measures is a way to check the construct validity of the dependent variable knowledge indices. Theoretically, local political interest should predict local political knowledge but not national political knowledge. Similarly, national political interest should predict national political knowledge but not local political knowledge. In the models presented in this paper, this is the case and some modicum of inferential confidence can be derived from this fact.

${ }^{44}$ Delli Carpini and Keeter, "What Americans Know About Politics and Why it Matters."

${ }^{45}$ Delli Carpini and Keeter, "What Americans Know About Politics and Why it Matters."

${ }^{46}$ Moy et al., "Political Correlates of Local News Media Use."

${ }^{47}$ McLeod, Scheufele, and Moy, "Community, Communication, and Participation: The Role of Mass Media and Interpersonal Discussion in Local Political Participation."

${ }^{48}$ Hutchings, "Political Context, Issue Salience, and Selective Attentiveness: Constituent Knowledge of the Clarence Thomas Confirmation Vote."

${ }^{49}$ PEJ, "The State of the News Media 2008."

${ }^{50}$ There is a strong positive correlation between internet access and income $(\mathrm{R}=.40, \mathrm{p} \leq .01)$ and education $(\mathrm{R}=$ $.37, \mathrm{p} \leq .01)$. Income and education, as depicted in Table 1 , are in turn strongly correlated with local political knowledge (income: $\mathrm{R}=.31, \mathrm{p} \leq .01$; education: $\mathrm{R}=.30, \mathrm{p} \leq .01$ ). 